\title{
Swimming pools quality risk assessment for heavy metal deposition and intake via oral and dermal exposure
}

\author{
Agomuo Emmanuel Nnabugwu ${ }^{1}$, Amadi Peter Uchenna ${ }^{2 *}$ [D \\ 'Department of Biochemistry, Imo State University Owerri, Imo State Nigeria; ${ }^{2}$ Department of Biochemistry, University of Port Harcourt, Choba Rivers \\ State Nigeria
}

The deplorable environmental conditions coupled to poor management practices employed by public swimming pool owners have led to suspicions over the safety of these recreational sites. This study was carried out to determine the physicochemical properties, heavy metal contents and accumulation, and associated risks of six swimming pools in Owerri, Capital of Imo State, Nigeria. Physicochemical analysis was conducted using standard methods while determination of heavy metals was carried out using an atomic absorption spectrophotometer. Results obtained showed that the turbidities and total dissolved solutes exceeded the Nigeria standard for water quality. Iron ( $\mathrm{Fe})$, cadmium $(\mathrm{Cd})$, mercury $(\mathrm{Hg})$, arsenic $(\mathrm{As})$, nickel $(\mathrm{Ni})$, and lead $(\mathrm{Pb})$ exceeded the drinking safety values from United States Environmental Protection Agency, National Standards for Drinking Water Quality, and World Health Organization, while selenium (Se), chromium ( $\mathrm{Cr}$ ), and zinc $(\mathrm{Zn})$ values fell within the permissible limits. From the bioaccumulation models applied, the enrichment factors showed anthropogenic source of deposition of the metals in all swimming pool while the heavy metal index were in a range of 27.30-70.19. For the risk assessment results, the chronic daily intake showed that $\mathrm{Hg}$, and As levels for all the swimming pools, and $\mathrm{Cu}$ for some swimming pools exceeded the oral reference doses, while the hazard quotient for $\mathrm{Hg}$ (5.65-16.95), As (2.26-3.77), and $\mathrm{Cu}$ (1.13-4.11) indicated potentials of causing related toxicities. This study has shown that the aesthetic quality of the swimming pools were compromised, and contained elevated levels of $\mathrm{Hg}$, As, and $\mathrm{Cu}$ significant enough to threaten the health safety of users of these swimming pools, which should instigate tough measures from Nigerian water regulatory bodies to ensure compliance from public swimming pool owners.

Keywords: Swimming pools; Bioaccumulation; Heavy metals; Risk assessment; Hazard quotient

\section{INTRODUCTION}

Water is one of the most important natural resources crucial in supporting life processes in both plants and animals [1]. Notwithstanding the importance of water to human existence, it poses serious threats by serving as a medium for disease transmission, when contaminated [2]. Groundwater accounts for $13 \%$ of the total water in earth, and of this percentage, only $2.3 \%$ is fit for consumption [2]. Groundwater pollution arising as a direct or indirect consequence of leakage of contaminants from leachates and massive industrialization, poses a worrisome trend to many countries as it is used for domestic purposes, and for various industrial and recreational activities [2]

Received: November 9, 2018 Accepted: June 22, 2019

Corresponding author: Amadi Peter Uchenna

Department of Biochemistry, Imo State University Owerri, Choba, Nigeria

E-mail: peter_amadi@uniport.edu.ng

This article is available from: $h t t p: / / e a h t . o r g$
Heavy metals are pollutants of primary importance [3] and their accumulation in groundwater above safe levels, affects humans and the entire ecosystem by limiting the usage of water [4]. They are predominantly deposited into water through sources such as fertilizers, agricultural wastes water, atmospheric particles, and combustion engine gases. At very minute concentrations above $3 \times 10^{-4}$ and $3 \times 10^{-5} \mathrm{mg} / \mathrm{L} /$ day, arsenic (As) and mercury $(\mathrm{Hg})$ respectively are capable of eliciting very serious toxic effects. Hence, the assessment and management of water quality is a topic of ecotoxicological relevance [5]. According to Amadi et al. [6], the provision of quality water amongst other benefits, enhances recreational opportunities such as in swimming pools that flourish as a resource generating venture in major cities of Nigeria. Swimming pools are recreational environments that provide both social and health benefits, and as such, should not cause harm to swimmers through either toxic substances or pathogenic microbes [7]. That notwithstanding, Barss et al. [8] noted that the rate of in- 
juries that occur particularly in swimming pools is underestimated, and greatly exceeds those in other environments. Some of these injuries include asthma $[9,10]$, skin and eye irritation [11, 12] and other skin infections [7] thus, requiring the establishment and enforcement of regulatory guidelines for the safety of the recreational environments [13]. Some measures such as chlorination of the pool water and refilling swimming pools every three days using both rain and borehole water are predominantly adopted by pool owners to ensure the mitigation of health risks associated with poor sanitary conditions for the pools. Prior to this present research, no reports exist in literature regarding the heavy metal status of swimming pools. Therefore, it becomes paramount to fill the gap in knowledge created by the paucity of information on the present contamination status of swimming pools, especially those situated in population dense and uncontrolled activityladen locations. It was on this foregoing that this study was carried out to determine the heavy metal contents and risks associated with oral ingestion of the heavy metals in six swimming pools situated in Owerri Capital city of Imo State, Nigeria.

\section{MATERIALS AND METHODS}

\section{Study area}

The six swimming pools used for this study, were hotel swimming pools cut across major roads in the Metropolis including Okigwe road, Amakohia road, World Bank road, and Port Harcourt road. The test samples were obtained directly from the swimming pools just before washing and refilling of the pool by the management, while the control samples were obtained from the source of refilling.

\section{Sample collection and preparation}

The samples $(20 \mathrm{~mL})$ were collected during the rainy season (June, 2018). Triplicate surface water samples were collected from mid-depth portions of each of the swimming pools, as well as their corresponding control samples using sterilized sample bottles. On collection of the samples, the sample bottles were first rinsed thrice with the swimming pool water samples, and stabilized using hydrochloric acid after sample collection. The samples were immediately conveyed to the laboratory for analysis.

\section{Sample analysis}

The temperature of the sample was measured by dipping a centigrade thermometer into the sample while the $\mathrm{pH}$, electrical conductivity, and total dissolved solute (TDS) was mea- sured using a HI 98129 portable $\mathrm{pH} / \mathrm{EC} / \mathrm{TDS} /$ temperature meter (Hanna Instrument, Inc. RI, USA). The alkalinity and dissolved oxygen contents were determined following instructions on HI3811 alkalinity test kit and HI3810 dissolved oxygen test kit (Hanna Instrument, Inc. RI, USA) while the turbidity was determined using a UV-VIS spectrophotometer at $860 \mathrm{~nm}$. The heavy metals; iron (Fe), cadmium (Cd), Hg, As, nickel (Ni), selenium (Se), chromium ( $\mathrm{Cr}$ ), lead $(\mathrm{Pb})$, zinc $(\mathrm{Zn})$, and copper $(\mathrm{Cu})$ were determined using an AA-670 atomic absorption spectrophotometer (Shimadzu Corporation. Kyoto, Japan). Briefly, the samples (20 mL) were digested using $15 \mathrm{~mL}$ mixture of perchloric acid, sulfuric acid, and nitric acid, in a ratio of 1:1:5. The mixture was heated in a heating mantle at $80{ }^{\circ} \mathrm{C}$ until a clear solution was obtained and afterwards, cooled and made up to $30 \mathrm{~mL}$ with $2 \%$ nitric acid and filtered. The heavy metal contents were thus determined in the digested samples using an AA-670 atomic absorption spectrophotometer (Shimadzu Corporation. Kyoto, Japan) after the preparation of a reference solution $[3,14]$.

\section{Determination of enrichment factor (EF) and heavy metal index (HMI)}

The enrichment factor (EF) is expressed mathematically as;

$$
\mathrm{EF}=\mathrm{Cn} / \mathrm{Ctn}
$$

where, $\mathrm{Cn}(\mathrm{mg} / \mathrm{L})$ represents the concentration of the element $\mathrm{n}$ at the test site, while $\mathrm{Ctn}$ (mg/L) stands for the concentration of the element $\mathrm{n}$ at the control site [14]. The EF is a tool used primarily to indicate the source of the contamination. EF $<1$ relates to a natural source of heavy metal deposition while $\mathrm{EF}>1$ relates to anthropogenic source of contamination

To calculate the heavy metal index (HMI), the following mathematical relationship was applied;

$$
\mathrm{HMI}=\sum_{i=1}^{n} \frac{C n}{S v}
$$

where Sv represents the standard values. The standard values were obtained as mean and standard deviations of permissible levels of heavy metal set by United States Environmental Protection Agency (USEPA) [15], Nigeria Standard Drinking Water Quality (NSDWQ) [16], and World Health Organization (WHO) [17]. The HMI which is equivalent to the contamination factor indicates the degree of heavy metal contamination in a site. Four categories exist for the HMI; when $\mathrm{HMI}<1$ implies low contamination, when $1 \leq \mathrm{HMI}<3$ implies moderate contamination, $3 \leq \mathrm{HMI}<6$ stands for high contamination, while $6 \leq \mathrm{HMI}$ implies very high contamination. 
Estimation of Chronic Daily Intake (CDI), and Hazard

\section{Quotient (HQ)}

The chronic daily intake via oral route (CDling; $\mathrm{mg} / \mathrm{kg} /$ day) was determined following the mathematical relationship below [18];

$$
\mathrm{CDI}_{\text {ing }}=\frac{C n \times I R \times E F \times E D}{B W \times A T}
$$

where IR (L/day) represents the ingestion rate, and $\mathrm{EF}$ (days/ year) represents exposure frequency, $\mathrm{ED}$ (year) represents the exposure duration, $\mathrm{BW}(\mathrm{Kg})$ represents the body weight and AT (days) represents averaging time. Standard IR for adult swimmers is $21 \mathrm{~mL} / \mathrm{h}$. From the swimming pool management data, the average swim time per day (exposure time) is $5.4 \mathrm{~h}$ (i.e. $5.4 \mathrm{~h} /$ days). Thus, the calculated $\mathrm{IR}(\mathrm{mL} /$ day $)=21 \times 5.4=$ $113.4 \mathrm{~mL} /$ day $=0.113 \mathrm{~L} /$ day.

EF was obtained from documentations of the six pool management and the average $\mathrm{EF}$ is represented below;

$$
\mathrm{EF}=\frac{59+51+65+54+48+45}{6}=53.6 \text { days } / \text { year }
$$

The BW was $70 \mathrm{~kg}$ representing the average BW of an adult [19]. To calculate ED, the ages of individuals recorded in the registers kept by the management of the swimming pools were obtained. The range of ages of individuals that use these pools were obtained and the ED calculated by subtracting the least age from the maximum age found in the registers for each swimming pool. The average ED was calculated:

$$
\begin{aligned}
& 4-68=64 \text { years ED for S.P1 } \\
& 5-61=56 \text { years ED for S.P2 } \\
& 4-73=69 \text { years ED for S.P3 } \\
& 4-64=60 \text { years ED for S.P4 } \\
& 5-60=55 \text { years ED for S.P5 } \\
& 4-61=57 \text { years ED for S.P6 }
\end{aligned}
$$$$
\text { Average } \mathrm{ED}=\frac{64+56+69+60+55+57}{6}=60.2 \text { years }
$$$$
\mathrm{AT}=\mathrm{EF} \times \mathrm{ED}=3226.72 \text { days }
$$

The chronic daily intake via the dermal route (CDIderm; mg/ $\mathrm{kg} /$ day) was calculated following the mathematical expression below;

$$
\mathrm{CDI}_{\text {derm }}=\frac{C n \times S A \times K p \times E T \times E F \times E D}{B W \times A T}
$$

$\mathrm{Cn}$ is the heavy metal concentration $(\mathrm{mg} / \mathrm{L}), \mathrm{SA}$ is the surface body area of an adult given as $18000 \mathrm{~cm} 2$ [20, 21], Kp (cm/h) represents the dermal permeability coefficient in water; 0.001 $\mathrm{cm} / \mathrm{h}$ for As, $\mathrm{Cd}$, Cu Se, and $\mathrm{Hg}, 0.0001 \mathrm{~cm} / \mathrm{h}$ for $\mathrm{Pb}, 0.002 \mathrm{~cm} /$ $\mathrm{h}$ for $\mathrm{Cr}$, and $0.0006 \mathrm{~cm} / \mathrm{h}$ for $\mathrm{Zn}$ [22], $0.001 \mathrm{~cm} / \mathrm{h}$ for Fe [23], and $0.0002 \mathrm{~cm} / \mathrm{h}$ for $\mathrm{Ni}$ [24], while ET, EF, ED, BW, and AT are as given above.

Hazard quotient (HQ) was calculated following the relationship below;

$$
\mathrm{HQ}=\frac{C D I}{R f D}
$$

where RfD is reference doses obtained from USEPA [25], Agomuo and Amadi [14], and Okereke and Amadi [26].

\section{Statistical analysis}

The data obtained was presented as mean \pm SD of triplicates. Analysis of the data was carried out using Statistical Package for Science and Social Sciences (SPSS) version 20, using one way analysis of variance (ANOVA) and the least standard deviations (LSD) at 95\% confidence interval (CI; $\mathrm{p}<0.05)$ considered as significant.

\section{RESULTS AND DISCUSSION}

Fig. 1-7 shows the physicochemical properties of six popular swimming pools situated at Owerri Capital city of Imo State Nigeria. The range of temperature, $\mathrm{pH}$ and turbidity are 24.7$29.6^{\circ} \mathrm{C}, 5.6-6.9$ and $38-90 \mathrm{NTU}$, respectively (Fig. 1, 2, 3). The

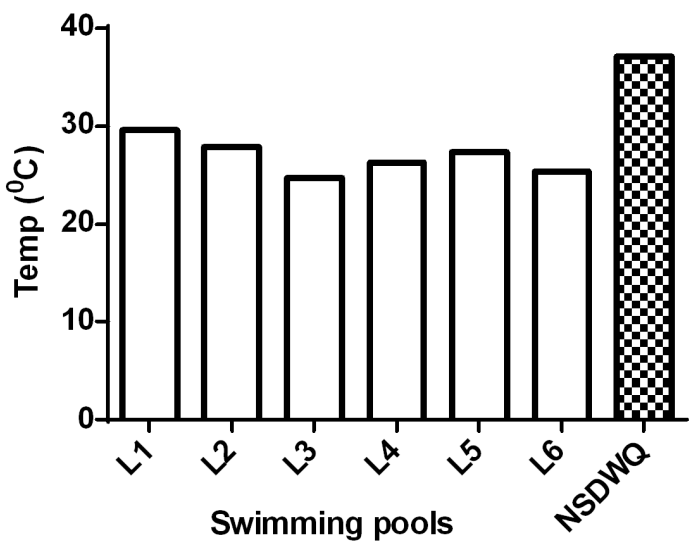

Figure 1. Temperatures of swimming pools

* NSDWQ=Nigeria Standard for Drinking Water Quality

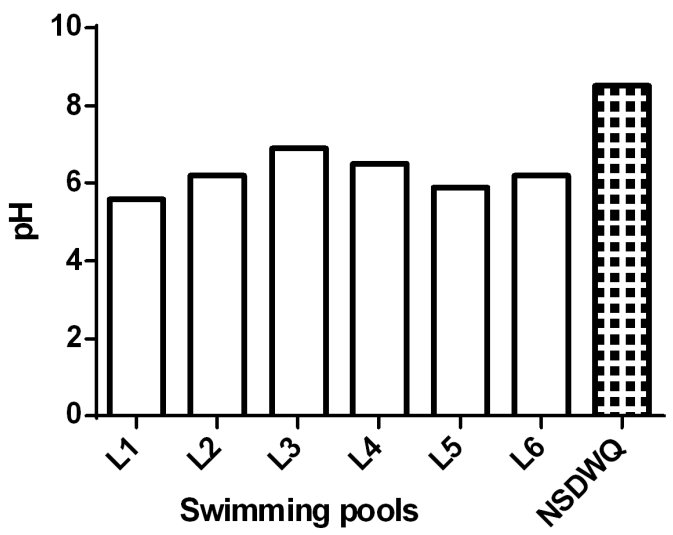

Figure 2. pH of swimming pools

* NSDWQ=Nigeria Standard for Drinking Water Quality 

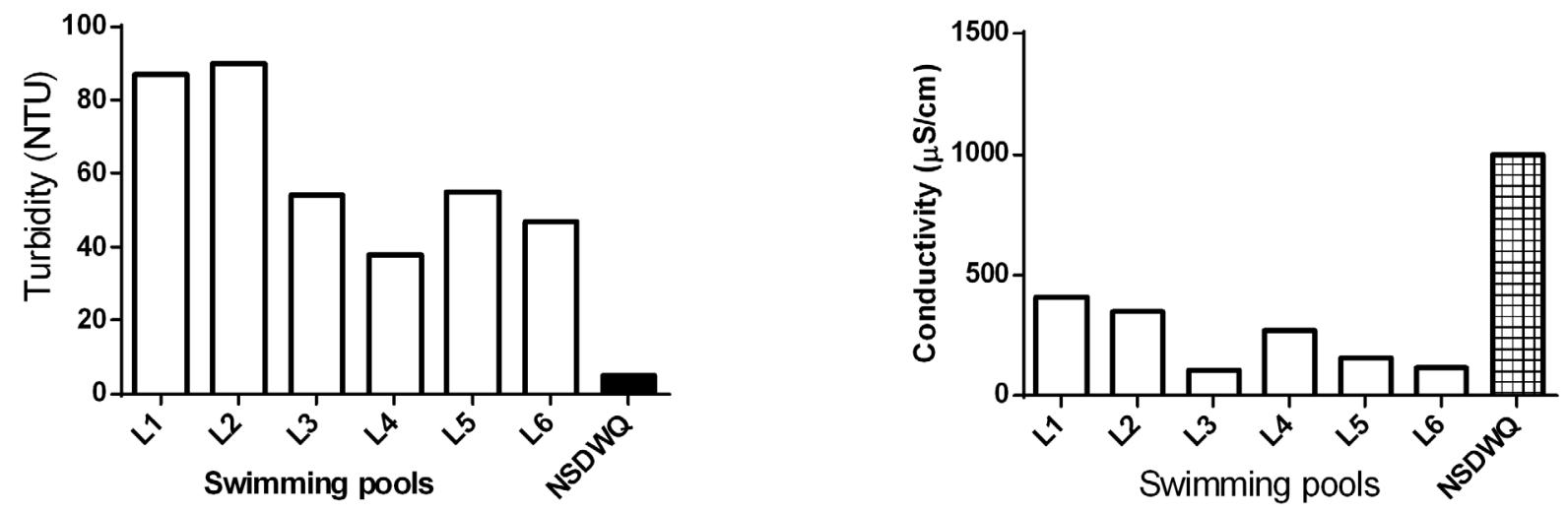

Figure 3. Turbidity of swimming pools

* NSDWQ=Nigeria Standard for Drinking Water Quality

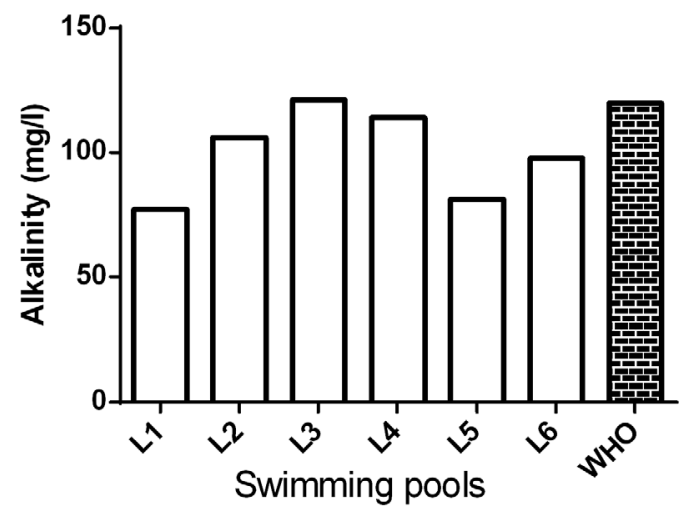

Figure 4. Alkalinity of swimming pools

*WHO=World Health Organization

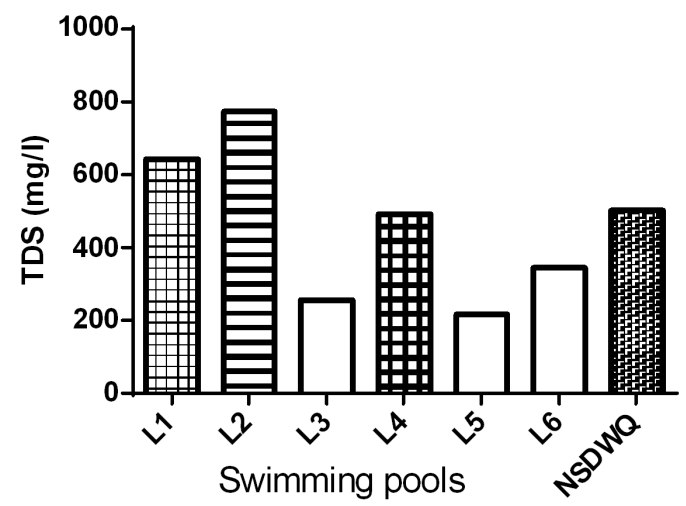

Figure 5. Total dissolved solute (TDS) of swimming pools

* NSDWQ=Nigeria Standard for Drinking Water Quality

range obtained for the alkalinity and TDS values are 77-119 $\mathrm{mg} / \mathrm{L}$ and 218-9773 mg/L respectively (Fig. 4, 5). The range of the conductivity and dissolved oxygen values are respectively in a range of 109.3-408.5 mg/L and 3.6-6.1 mg/L (Fig. 6, 7). The

Figure 6. Conductivity of swimming pools

* NSDWQ=Nigeria Standard for Drinking Water Quality

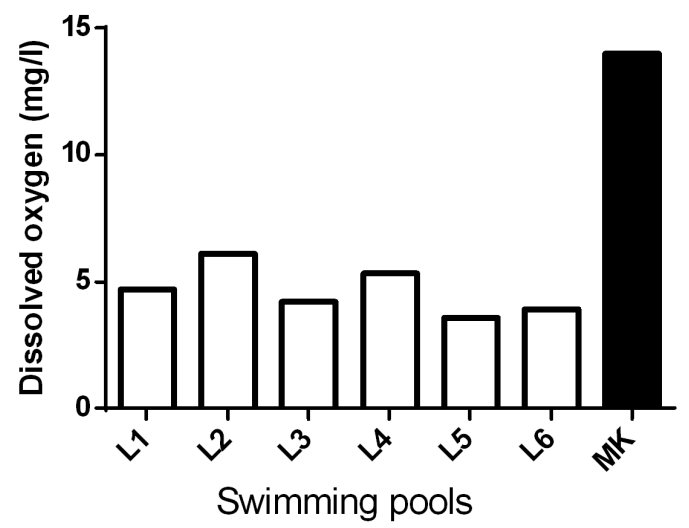

Figure 7. Dissolved oxygen of swimming pools

${ }^{*}$ MK= Manoj and Avinash [17]

temperature, $\mathrm{pH}$, alkalinity, dissolved oxygen, and conductivity recorded for all the swimming pools in this study were still within the regulatory limits adopted from NSDWQ, WHO, and Manoj and Avinash [17].

The turbidity of all the swimming pools shown in Fig. 3 exceeds the permissible limit. This has the potentials to reduce the aesthetic quality of the pools and poses negative impact on the recreational activities by reducing the patronage of the pools, and causes gastrointestinal related diseases [27]. Also, the TDS exceeds the reference value in some swimming pools. The TDS estimates the total organic and inorganic solids in the pools, and from this result, indicates that the aesthetic quality of those swimming pools have been compromised by a broad range of substances. The elevated levels of turbidity and TDS of the swimming pools could have occurred as a result of depositions of contaminants because of situating these swimming pools in the heart of the city without adequate internal safety measures.

Table 1 summarizes the $\mathrm{Fe}, \mathrm{Cd}, \mathrm{Hg}$, As, and Ni contents of six 
Table 1. Iron (Fe), cadmium (Cd), mercury ( $\mathrm{Hg}$ ), arsenic (As), and nickel (Ni) contents (mg/L) of swimming pools

\begin{tabular}{|c|c|c|c|c|c|}
\hline Swimming pool & $\mathrm{Fe}$ & $\mathrm{Cd}$ & $\mathrm{Hg}$ & As & $\mathrm{Ni}$ \\
\hline \multicolumn{6}{|l|}{$\mathrm{L}_{1}$} \\
\hline Test & $3.86 \pm 0.9^{a}$ & $0.03 \pm 0.0^{a}$ & $0.02 \pm 0.0^{\mathrm{a}}$ & $0.08 \pm 0.01^{\mathrm{a}}$ & $0.13 \pm 0.01^{a}$ \\
\hline Control & $1.06 \pm 0.3^{b}$ & BDL & BDL & $0.02 \pm 0.0^{b}$ & $0.06 \pm 0.0^{b}$ \\
\hline Standard & $0.20 \pm 0.1^{c}$ & $0.003 \pm 0.0^{b}$ & $0.001 \pm 0.0^{b}$ & $0.01 \pm 0.0^{b}$ & $0.02 \pm 0.0^{c}$ \\
\hline \multicolumn{6}{|l|}{$\mathrm{L}_{2}$} \\
\hline Test & $4.19 \pm 1.31^{\mathrm{a}}$ & $B D L$ & $0.03 \pm 0.0^{a}$ & BDL & $0.09 \pm 0.03^{a}$ \\
\hline Control & $0.71 \pm 0.2^{b}$ & BDL & $0.01 \pm 0.0^{\mathrm{a}}$ & BDL & $0.03 \pm 0.0^{b}$ \\
\hline Standard & $0.20 \pm 0.1^{c}$ & $0.003 \pm 0.0$ & $0.001 \pm 0.0^{c}$ & $0.01 \pm 0.0$ & $0.02 \pm 0.0^{b}$ \\
\hline \multicolumn{6}{|l|}{$\mathrm{L}_{3}$} \\
\hline Test & $1.78 \pm 0.40^{\mathrm{a}}$ & $0.02 \pm 0.0^{a}$ & $\mathrm{BDL}$ & $0.03 \pm 0.0^{\mathrm{a}}$ & $0.07 \pm 0.01^{a}$ \\
\hline Control & $0.35 \pm 0.02^{b}$ & $0.01 \pm 0.0^{\mathrm{a}}$ & BDL & $0.01 \pm 0.0^{b}$ & $0.02 \pm 0.0^{b}$ \\
\hline Standard & $0.20 \pm 0.1^{b}$ & $0.003 \pm 0.0^{b}$ & $0.001 \pm 0.0$ & $0.01 \pm 0.0^{b}$ & $0.02 \pm 0.0^{b}$ \\
\hline \multicolumn{6}{|l|}{$\mathrm{L}_{4}$} \\
\hline Test & $3.45 \pm 0.77^{\mathrm{a}}$ & $0.01 \pm 0.0^{\mathrm{a}}$ & $0.01 \pm 0.0^{\mathrm{a}}$ & $0.05 \pm 0.02^{\mathrm{a}}$ & $0.03 \pm 0.0^{\mathrm{a}}$ \\
\hline Control & $1.21 \pm 0.31^{b}$ & $0.01 \pm 0.0^{\mathrm{a}}$ & BDL & $0.02 \pm 0.0^{\mathrm{b}}$ & $\mathrm{BDL}$ \\
\hline Standard & $0.20 \pm 0.1^{c}$ & $0.003 \pm 0.0^{b}$ & $0.001 \pm 0.0^{b}$ & $0.01 \pm 0.0^{b}$ & $0.02 \pm 0.0^{\mathrm{a}}$ \\
\hline \multicolumn{6}{|l|}{$\mathrm{L}_{5}$} \\
\hline Test & $0.93 \pm 0.22^{\mathrm{a}}$ & $0.02 \pm 0.0^{\mathrm{a}}$ & $\mathrm{BDL}$ & $\mathrm{BDL}$ & $0.06 \pm 0.01^{a}$ \\
\hline Control & $0.31 \pm 0.07^{b}$ & BDL & BDL & BDL & $0.02 \pm 0.0^{b}$ \\
\hline Standard & $0.20 \pm 0.1^{b}$ & $0.003 \pm 0.0^{b}$ & $0.001 \pm 0.0$ & $0.01 \pm 0.0$ & $0.02 \pm 0.0^{b}$ \\
\hline \multicolumn{6}{|l|}{$\mathrm{L}_{6}$} \\
\hline Test & $0.51 \pm 0.13^{\mathrm{a}}$ & $0.03 \pm 0.0^{\mathrm{a}}$ & $0.01 \pm 0.0^{\mathrm{a}}$ & $0.06 \pm 0.02^{\mathrm{a}}$ & $0.05 \pm 0.02^{\mathrm{a}}$ \\
\hline Control & $0.41 \pm 0.11^{\mathrm{a}}$ & $0.01 \pm 0.0^{\mathrm{a}}$ & BDL & $0.01 \pm 0.0^{\mathrm{b}}$ & $0.03 \pm 0.0^{\mathrm{ab}}$ \\
\hline Standard & $0.20 \pm 0.1^{b}$ & $0.003 \pm 0.0^{b}$ & $0.001 \pm 0.0^{c}$ & $0.01 \pm 0.0^{\mathrm{b}}$ & $0.02 \pm 0.0^{b}$ \\
\hline
\end{tabular}

${ }^{*} \mathrm{~L}_{1}-\mathrm{L}_{6}=$ Location $1-6$

* Values are means and standard deviations of triplicate determinations.

* For each swimming pool, values bearing dissimilar superscript letter (s). ${ }^{a, b}$ down the column denote that the mean difference is significant at $p<0.05$. BDL $=$ Below Detection Level.

popular swimming pools located in the heart of Owerri Capital, Imo State. From the result, the Fe contents at each of the swimming pools were significantly higher than the controls and standard values, ranging from $0.51-4.19 \mathrm{mg} / \mathrm{L}$ and $0.31-$ $1.21 \mathrm{mg} / \mathrm{L}$, respectively. Also, the $\mathrm{Cd}$ and $\mathrm{Hg}$ contents significantly exceeded the baseline values but occurred below detection levels at $\mathrm{L}_{2}, \mathrm{~L}_{3}$ and $\mathrm{L}_{5}$, respectively. The concentration of As and $\mathrm{Ni}$ also significantly exceeded both the control and baseline values, except at $\mathrm{L}_{2}$ and $\mathrm{L}_{5}$ where As was respectively undetected and equivalent to the control. No significant difference was observed between the control and standard values for both As and Ni. These findings pose serious concerns due to the significant numbers of activities and patronage of these commercial swimming pools. The As contents are possibly deposited into the pools from agricultural and mining activities, and leaching from toxic dumpsites [28, 29]. Pacyna and Pacyna [30] suggested that windblown dusts, oil combustion and incinerations of wastes around these pools primarily contributes to the deposition of Ni into these pools. The Fe contents of the swimming pools were higher than those of boreholes in Owerri [31], however, comparable with some control values in this study. The significantly higher control values in some of the swimming pools when compared to standard values observed in this study may relate to the usage of rain water to refill the pools. Agomuo and Amadi, [14] earlier flagged the excessive contents of $\mathrm{Cd}$ and $\mathrm{Hg}$ in Owerri metropolis which could have contributed to the elevated amounts of heavy metals in this present study. It is possible that situating swimming pools at the heart of the city increases their susceptibility to $\mathrm{Cd}$ and $\mathrm{Hg}$ contamination. The report of Amadi [5] for the As and Ni contents of a water body in close proximity to these swimming pools in this study, agrees with the findings of this study. Thus, this implicates the environment possibly contaminated with As and Ni.

Table 2 shows the $\mathrm{Se}, \mathrm{Cr}, \mathrm{Pb}, \mathrm{Zn}$, and Cu levels of swimming pools in Owerri Metropolis. The Se and $\mathrm{Cr}$ contents of the swimming pools were within the permissible limits set by regulatory agencies. The concentration of Se was only recorded in one control sample while $\mathrm{Cr}$ levels of the control samples were also within the permissible limit. The Pb levels at all swimming pools significantly exceeded the permissible limits. Further, only half of the total swimming pools assessed contained significantly higher $\mathrm{Zn}$ levels than their baseline value, while $\mathrm{Cu}$ contents of the swimming pools were within the permissible limit. Notwithstanding that some of these heavy metals like $\mathrm{Se}, \mathrm{Zn}$ and $\mathrm{Cu}$ are required for normal body metabolic 
Table 2. Selenium (Se), chromium (Cr), lead $(\mathrm{Pb})$, zinc $(\mathrm{Zn})$, and copper $(\mathrm{Cu})$ contents (mg/L) of swimming pools

\begin{tabular}{|c|c|c|c|c|c|}
\hline Swimming pools & Se & $\mathrm{Cr}$ & $\mathrm{Pb}$ & $\mathrm{Zn}$ & $\mathrm{Cu}$ \\
\hline \multicolumn{6}{|l|}{$L_{1}$} \\
\hline Test & $\mathrm{BDL}$ & $0.05 \pm 0.0^{\mathrm{a}}$ & $0.05 \pm 0.01^{\mathrm{a}}$ & $0.63 \pm 0.2^{\mathrm{a}}$ & $0.33 \pm 0.08^{a}$ \\
\hline Control & BDL & BDL & $0.02 \pm 0.0^{b}$ & $0.41 \pm 0.1^{\mathrm{a}}$ & $0.08 \pm 0.02^{b}$ \\
\hline Standard & $0.03 \pm 0.02$ & $0.05 \pm 0.0^{\mathrm{a}}$ & $0.01 \pm 0.0^{\mathrm{b}}$ & $4.33 \pm 1.2^{b}$ & $1.33 \pm 0.60^{\circ}$ \\
\hline \multicolumn{6}{|l|}{$\mathrm{L}_{2}$} \\
\hline Test & BDL & $0.07 \pm 0.01^{\mathrm{a}}$ & $0.09 \pm 0.02^{\mathrm{a}}$ & $3.87 \pm 1.01^{\mathrm{a}}$ & $0.50 \pm 0.1^{\mathrm{a}}$ \\
\hline Control & BDL & $0.02 \pm 0.0^{b}$ & $0.02 \pm 0.0^{b}$ & $0.24 \pm 0.06^{b}$ & $\mathrm{BDL}$ \\
\hline Standard & $0.03 \pm 0.02$ & $0.05 \pm 0.0^{\mathrm{a}}$ & $0.01 \pm 0.0^{b}$ & $4.33 \pm 1.2^{\mathrm{a}}$ & $1.33 \pm 0.60^{b}$ \\
\hline \multicolumn{6}{|l|}{$\mathrm{L}_{3}$} \\
\hline Test & $0.02 \pm 0.0^{\mathrm{a}}$ & $0.04 \pm 0.0^{\mathrm{a}}$ & $0.08 \pm 0.02^{\mathrm{a}}$ & $3.11 \pm 0.92^{\mathrm{a}}$ & $0.21 \pm 0.05^{\mathrm{a}}$ \\
\hline Control & $\mathrm{BDL}$ & $0.01 \pm 0.0^{\mathrm{b}}$ & $0.04 \pm 0.01^{b}$ & $0.93 \pm 0.14^{b}$ & $0.20 \pm 0.09^{a}$ \\
\hline Standard & $0.03 \pm 0.02^{\mathrm{a}}$ & $0.05 \pm 0.0^{\mathrm{a}}$ & $0.01 \pm 0.0^{c}$ & $4.33 \pm 1.2^{\mathrm{a}}$ & $1.33 \pm 0.60^{b}$ \\
\hline \multicolumn{6}{|l|}{$\mathrm{L}_{4}$} \\
\hline Test & $0.01 \pm 0.0^{\mathrm{a}}$ & BDL & $0.05 \pm 0.01^{\mathrm{a}}$ & $1.90 \pm 0.50^{\mathrm{a}}$ & $1.82 \pm 0.31^{\mathrm{a}}$ \\
\hline Control & $\mathrm{BDL}$ & $\mathrm{BDL}$ & $0.01 \pm 0.0^{b}$ & $1.04 \pm 0.29^{b}$ & $0.30 \pm 0.05^{b}$ \\
\hline Standard & $0.03 \pm 0.02^{\mathrm{a}}$ & $0.05 \pm 0.0$ & $0.01 \pm 0.0^{b}$ & $4.33 \pm 1.2^{c}$ & $1.33 \pm 0.60^{\mathrm{a}}$ \\
\hline \multicolumn{6}{|l|}{$L_{5}$} \\
\hline Test & $0.03 \pm 0.0^{\mathrm{a}}$ & $0.07 \pm 0.02^{\mathrm{a}}$ & $0.09 \pm 0.04^{\mathrm{a}}$ & $4.43 \pm 0.88^{\mathrm{a}}$ & $0.74 \pm 0.13^{\mathrm{a}}$ \\
\hline Control & $0.01 \pm 0.0^{b}$ & $0.01 \pm 0.0^{b}$ & $0.02 \pm 0.0^{\mathrm{b}}$ & $1.21 \pm 0.04^{\mathrm{b}}$ & $\mathrm{BDL}$ \\
\hline Standard & $0.03 \pm 0.02^{\mathrm{a}}$ & $0.05 \pm 0.0^{\mathrm{a}}$ & $0.01 \pm 0.0^{\mathrm{b}}$ & $4.33 \pm 1.2^{\mathrm{a}}$ & $1.33 \pm 0.60^{\circ}$ \\
\hline \multicolumn{6}{|l|}{$\mathrm{L}_{6}$} \\
\hline Test & $0.01 \pm 0.0^{\mathrm{a}}$ & $0.04 \pm 0.0^{\mathrm{a}}$ & $0.06 \pm 0.02^{\mathrm{a}}$ & $2.75 \pm 0.61^{a}$ & $1.32 \pm 0.38^{\mathrm{a}}$ \\
\hline Control & $\mathrm{BDL}$ & $\mathrm{BDL}$ & $0.04 \pm 0.01^{a}$ & $2.16 \pm 0.93^{\mathrm{a}}$ & $0.29 \pm 0.05^{b}$ \\
\hline Standard & $0.03 \pm 0.02^{\mathrm{a}}$ & $0.05 \pm 0.0^{\mathrm{a}}$ & $0.01 \pm 0.0^{\mathrm{b}}$ & $4.33 \pm 1.2^{c}$ & $1.33 \pm 0.60^{\mathrm{a}}$ \\
\hline
\end{tabular}

${ }^{*} L_{1}-L_{6}=$ Location $1-6$.

* Values are means and standard deviations of triplicate determinations.

* For each swimminng pool, values bearing dissimilar superscript letter(s) $(a, b)$ down the column denote that the mean difference is significant at $p<0.05$. BDL $=B e l o w$ Detection Level.

Table 3. Enrichment factor (EF) of heavy metal depositions in swimming pools

\begin{tabular}{lccccccccccc}
\hline Swimming pool & $\mathrm{Fe}$ & $\mathrm{Cd}$ & $\mathrm{Hg}$ & $\mathrm{As}$ & $\mathrm{Ni}$ & $\mathrm{Se}$ & $\mathrm{Cr}$ & $\mathrm{Pb}$ & $\mathrm{Zn}$ & $\mathrm{Cu}$ \\
\hline $\mathrm{L}_{1}$ & 3.58 & - & - & 4.00 & 2.17 & - & - & 1.50 & 1.54 & 4.13 \\
$\mathrm{~L}_{2}$ & 5.90 & - & 3.00 & - & 3.00 & - & 3.50 & 4.50 & 16.13 & - \\
$\mathrm{L}_{3}$ & 5.09 & 2.00 & - & 3.00 & 3.50 & - & 4.00 & 2.00 & 3.34 & 1.05 \\
$\mathrm{~L}_{4}$ & 2.85 & 1.00 & - & 2.50 & - & - & - & 5.00 & 1.83 & 6.06 \\
$\mathrm{~L}_{5}$ & 3.00 & - & - & - & 3.00 & 3.00 & 7.00 & 4.50 & 3.66 & - \\
$\mathrm{L}_{6}$ & 1.24 & 3.00 & - & 6.00 & 1.67 & - & - & 1.50 & 1.27 & 4.55 \\
\hline
\end{tabular}

${ }^{*} \mathrm{~L}_{1}-\mathrm{L}_{6}=$ Location $1-6$.

* Iron (Fe). cadmium (Cd), mercury (Hg), arsenic (As), nickel (Ni), selenium (Se), chromium (Cr), lead (Pb), zinc (Zn), and copper (Cu).

Table 4. Heavy metal index (HMI) of swimming pools

\begin{tabular}{lccccccccccc}
\hline Swimming pools & $\mathrm{Fe}$ & $\mathrm{Cd}$ & $\mathrm{Hg}$ & $\mathrm{As}$ & $\mathrm{Ni}$ & $\mathrm{Se}$ & $\mathrm{Cr}$ & $\mathrm{Pb}$ & $\mathrm{Zn}$ & $\mathrm{Cu}$ & $\mathrm{Ml}$ \\
\hline $\mathrm{L}_{1}$ & 19.30 & 10.00 & 20.00 & 8.00 & 6.5 & - & 1.00 & 5.00 & 0.14 & 0.25 & 70.19 \\
$\mathrm{~L}_{2}$ & 20.95 & - & 30.00 & - & 4.5 & - & 2.33 & 9.00 & 0.89 & 0.38 & 68.05 \\
$\mathrm{~L}_{3}$ & 8.90 & 6.67 & - & 3.00 & 3.5 & 0.66 & 0.80 & 6.00 & 0.72 & 0.16 & 30.41 \\
$\mathrm{~L}_{4}$ & 17.25 & 3.33 & 10.00 & 5.00 & 1.5 & 0.33 & - & 5.00 & 0.44 & 1.37 & 44.22 \\
$\mathrm{~L}_{5}$ & 4.65 & 6.67 & - & - & 3.00 & 1.00 & 1.40 & 9.00 & 1.02 & 0.56 & 27.30 \\
$\mathrm{~L}_{6}$ & 2.55 & 10.00 & 10.00 & 6.00 & 2.5 & 0.33 & 0.80 & 6.00 & 0.64 & 0.99 & 39.81 \\
\hline
\end{tabular}

${ }^{*} L_{1}-L_{6}=$ Location $1-6$.

* Iron (Fe). cadmium (Cd), mercury (Hg), arsenic (As), nickel (Ni), selenium (Se), chromium (Cr), lead (Pb), zinc (Zn), and copper (Cu).

processes, excessive intake could become very poisonous [32]. In this study, though none of those metals including $\mathrm{Cr}$ exceeded the baseline values, imminent strategies are required to halt their deposition into these swimming pools. The signif- icantly high level of $\mathrm{Pb}$ in these swimming pools may not be surprising due to proximity of these swimming pools to dump sites and metallic constructions firms during road works, and filling station reservoir tanks for petroleum products. Thus, the 
Table 5. Chronic daily intake (CDl; mg/kg/day) of heavy metals in swimming pools via oral and dermal routes

\begin{tabular}{|c|c|c|c|c|c|c|c|c|c|c|}
\hline \multicolumn{11}{|c|}{ CDI BY ORAL EXPOSURE } \\
\hline Swimming pool & $\mathrm{Fe}\left(\times 10^{-3}\right)$ & $\mathrm{Cd}\left(\times 10^{-5}\right)$ & $\mathrm{Hg}\left(\times 10^{-5}\right)$ & As $\left(\times 10^{-4}\right)$ & $\mathrm{Ni}\left(\times 10^{-4}\right)$ & Se $\left(\times 10^{-5}\right)$ & $\operatorname{Cr}\left(\times 10^{-5}\right)$ & $\mathrm{Pb}\left(\times 10^{-5}\right)$ & $\operatorname{Zn}\left(\times 10^{-3}\right)$ & $\mathrm{Cu}\left(\times 10^{-4}\right)$ \\
\hline$L_{1}$ & 6.21 & 4.85 & 3.22 & 1.28 & 2.04 & - & 8.05 & 8.05 & 1.01 & 7.46 \\
\hline $\mathrm{L}_{2}$ & 6.74 & - & 4.85 & - & 1.45 & - & 11.27 & 14.49 & 6.23 & 8.05 \\
\hline $\mathrm{L}_{3}$ & 2.86 & 3.22 & - & 0.49 & 1.12 & 3.22 & 6.44 & 12.88 & 5.01 & 3.38 \\
\hline $\mathrm{L}_{4}$ & 5.55 & 1.61 & 1.61 & 0.81 & 0.48 & 1.61 & - & 8.05 & 3.06 & 29.30 \\
\hline $\mathrm{L}_{5}$ & 1.49 & 3.22 & - & - & 0.97 & 4.83 & 11.27 & 14.49 & 7.13 & 11.91 \\
\hline $\mathrm{L}_{6}$ & 0.80 & 4.85 & 1.61 & 0.97 & 0.81 & 1.61 & 6.44 & 9.66 & 4.43 & 21.25 \\
\hline \multicolumn{11}{|c|}{ CDI BY DERMAL EXPOSURE } \\
\hline Swimming pool & $\mathrm{Fe}\left(\times 10^{-5}\right)$ & $\mathrm{Cd}\left(\times 10^{-6}\right)$ & $\mathrm{Hg}\left(\times 10^{-7}\right)$ & As $\left(\times 10^{-6}\right)$ & $\mathrm{Ni}\left(\times 10^{-7}\right)$ & Se $\left(\times 10^{-7}\right)$ & $\mathrm{Cr}\left(\times 10^{-6}\right)$ & $\mathrm{Pb}\left(\times 10^{-7}\right)$ & $\operatorname{Zn}\left(\times 10^{-6}\right)$ & $\mathrm{Cu}\left(\times 10^{-6}\right)$ \\
\hline $\mathrm{L}_{1}$ & 8.91 & 0.69 & 4.62 & 1.84 & 6.01 & - & 2.31 & 1.15 & 0.86 & 7.62 \\
\hline $\mathrm{L}_{2}$ & 11.34 & - & 6.93 & - & 4.15 & - & 3.23 & 2.07 & 5.34 & 11.55 \\
\hline $\mathrm{L}_{3}$ & 4.11 & 0.46 & - & 0.69 & 3.23 & 4.62 & 1.85 & 1.84 & 4.29 & 4.85 \\
\hline $\mathrm{L}_{4}$ & 7.96 & 0.23 & 2.31 & 1.12 & 1.39 & 2.31 & - & 1.15 & 2.62 & 42.04 \\
\hline $\mathrm{L}_{5}$ & 2.15 & 0.46 & - & - & 2.77 & 6.93 & 3.23 & 2.07 & 6.11 & 17.09 \\
\hline $\mathrm{L}_{6}$ & 1.17 & 0.69 & 2.31 & 1.39 & 2.31 & 2.31 & 1.85 & 1.38 & 3.79 & 30.49 \\
\hline $\mathrm{RfD}^{\star \star}$ & 0.7 & $1 \times 10^{-3}$ & $4 \times 10^{-5}$ & $3 \times 10^{-4}$ & $2 \times 10^{-2}$ & $5 \times 10^{-3}$ & $3 \times 10^{-3}$ & $3.5 \times 10^{-3}$ & $3 \times 10^{-1}$ & $1 \times 10^{-2}$ \\
\hline
\end{tabular}

${ }^{*} L_{1}-L_{6}=$ Location 1-6.

* Iron (Fe). cadmium (Cd), mercury (Hg), arsenic (As), nickel (Ni), selenium (Se), chromium (Cr), lead (Pb), zinc (Zn), and copper (Cu).

${ }^{\star *} \mathrm{RfD}$ : Reference dose.

Table 6. Hazard quotient $(\mathrm{HQ})$ of heavy metals and Total Hazard Index of swimming pools via oral and dermal exposure routes

\begin{tabular}{|c|c|c|c|c|c|c|}
\hline Swimming pool & $\mathrm{L}_{1}$ & $\mathrm{~L}_{2}$ & $\mathrm{~L}_{3}$ & $\mathrm{~L}_{4}$ & $\mathrm{~L}_{5}$ & $\mathrm{~L}_{6}$ \\
\hline $\mathrm{Fe}_{\text {ing }}\left(\times 10^{-3}\right)$ & 8.87 & 9.62 & 4.08 & 7.92 & 2.12 & 1.14 \\
\hline Derm $\left(\times 10^{-5}\right)$ & 12.72 & 16.20 & 5.87 & 11.37 & 3.07 & 1.67 \\
\hline $\mathrm{Cd}_{\text {ing }}\left(\times 10^{-2}\right)$ & 4.85 & - & 3.22 & 1.61 & 3.22 & 4.85 \\
\hline Derm $\left(\times 10^{-3}\right)$ & 0.69 & - & 0.46 & 0.23 & 0.46 & 0.69 \\
\hline $\mathrm{Hg}$ ing & 0.81 & 1.21 & - & 0.40 & - & 0.40 \\
\hline Derm & 1.15 & 1.73 & - & 0.58 & - & 0.58 \\
\hline As ing & 0.43 & - & 0.16 & 0.27 & - & 0.32 \\
\hline $\operatorname{Derm}\left(\times 10^{-2}\right)$ & 0.61 & - & 0.23 & 0.37 & - & 0.46 \\
\hline $\mathrm{Ni}$ ing $\left(\times 10^{-2}\right)$ & 1.02 & 0.72 & 0.56 & 0.24 & 0.48 & 0.40 \\
\hline Derm $\left(\times 10^{-5}\right)$ & 3.00 & 2.07 & 1.61 & 0.69 & 1.38 & 1.15 \\
\hline $\mathrm{Se}_{\text {ing }}\left(\times 10^{-2}\right)$ & - & - & 0.64 & 0.32 & 0.96 & 0.32 \\
\hline $\operatorname{Derm}\left(\times 10^{-4}\right)$ & - & - & 0.92 & 0.46 & 1.38 & 0.46 \\
\hline $\mathrm{Cr}_{\text {ing }}\left(\times 10^{-2}\right)$ & 2.68 & 3.75 & 2.14 & - & 3.75 & 2.14 \\
\hline Derm $\left(\times 10^{-3}\right)$ & 0.77 & 1.07 & 0.62 & - & 1.07 & 0.62 \\
\hline $\mathrm{Pb}_{\text {ing }}\left(\times 10^{-2}\right)$ & 2.30 & 4.83 & 4.23 & 2.30 & 4.83 & 0.39 \\
\hline Derm $\left(\times 10^{-4}\right)$ & 0.33 & 0.59 & 0.53 & 0.33 & 0.59 & 0.39 \\
\hline $\mathrm{Pb}_{\text {ing }}\left(\times 10^{-2}\right)$ & 0.33 & 2.07 & 1.67 & 1.02 & 2.37 & 1.47 \\
\hline Derm $\left(\times 10^{-5}\right)$ & 0.28 & 1.78 & 1.43 & 0.87 & 2.03 & 1.26 \\
\hline $\mathrm{Cu}_{\text {ing }}\left(\times 10^{-2}\right)$ & 7.46 & 8.05 & 3.38 & 29.30 & 11.91 & 21.25 \\
\hline Derm $\left(\times 10^{-4}\right)$ & 7.62 & 11.55 & 4.85 & 42.04 & 17.09 & 30.49 \\
\hline
\end{tabular}

${ }^{*} \mathrm{~L}_{1}-\mathrm{L}_{6}=$ Location 1-6.

* Iron (Fe). cadmium (Cd), mercury (Hg), arsenic (As), nickel (Ni), selenium (Se), chromium (Cr), lead (Pb), zinc (Zn), and copper (Cu).

leaching of $\mathrm{Pb}$, and possibly some other heavy metals is obtainable. In addition to this, most of these swimming pools are refilled through old pipes capable of depositing $\mathrm{Pb}$ materials into the water and its significantly excessive $\mathrm{Pb}$ levels.

Table 3 and 4 represents EF and HMI of six commercial swimming pools situated at Owerri Metropolis. EF is an essential tool that indicates the source of heavy metal pollution at a given location [26]. EF $>1$ indicates anthropogenic sources of contamination while $\mathrm{EF}<1$ shows natural sources of deposi- tion of these metals. In Table 3, all the swimming pools record EF values $>1$ for all the heavy metals detected, whereas some metals in some pools were found below detection limits, indicating anthropogenic sources of heavy metal deposition. Again, the locations of these swimming pools, coupled to perhaps the activities that occur, have been shown to be contributory to the elevations of heavy metal contents of these swimming pools. While describing the usefulness of HMI in determining water quality, Gohera et al., [33] posited its effective- 
ness as a parameter for assessing the pollution status of a water sample. It cumulatively takes account of all the levels of each heavy metal evaluated, and when above unity (1), shows that the water is unsafe for consumption. From Table 4, all the swimming pools are highly threatened with heavy metal pollution with $\mathrm{L}_{1}$ followed closely by $\mathrm{L}_{2}$ the most threatened, and $\mathrm{L}_{5}$ the least threatened.

Table 5 and 6 show the CDI via oral and dermal exposure and the HQ of six commercial swimming pools situated at Owerri Metropolis. The CDI result for Fe and Cd implies that their levels of occurrences were still below the reference doses while their respective HQ values indicate that at those levels in which patrons of those swimming pools are unlikely to encounter any Fe or Cd related toxicities. This was the same case for $\mathrm{Ni}$, Se, $\mathrm{Cr}, \mathrm{Pb}$, and $\mathrm{Zn}$. However, the deposition of these heavy metals into these swimming pools has to be curtailed. Results for oral intake of $\mathrm{Hg}$ especially at $\mathrm{L}_{1}$ and $\mathrm{L}_{2}$ exceeded their respective reference doses as shown in Table 5 while in Table 6, the sum of HQs for $\mathrm{L}_{2}$ exceeded 1, implying the potentials of the pool at $\mathrm{L}_{2}$ to causing $\mathrm{Hg}$ poisoning. Also, oral intake levels of As attained a close level to the reference dose, thus requiring very imminent measures that can effectively curtail the deposition of As in these pools. By dermal exposure, none of the deposited heavy metals exceeded their respective reference doses hence may not portend any toxic risk. Hg toxicities could manifest as desquamation [34], central nerve system and autoimmune diseases [35] and Young's syndrome [34], while for As poisoning, cardiovascular and skin diseases, abdominal pain and cancer could result [37]. Also, as shown in Table 6, only $\mathrm{L}_{2}$ among six swimming pools portends the potentials of eliciting metal toxicities having shown HQ value greater than 1 . In addition, the toxic risk of the cumulative contents of all the heavy metals in each of the swimming pools indicates two of the swimming pools are unsafe.

\section{Conclusion}

This study has shown that the aesthetic quality of the swimming pools was compromised, and contained elevated levels of $\mathrm{Hg}$, As, and $\mathrm{Cu}$, which were significant enough to threaten the health safety of users of these swimming pools users. Thus, imminent strategies are required by the regulatory bodies to checkmate the safety processes applied by the management of these commercial swimming pools to prevent the heavy metal contamination, and enforce compliance to standard approaches. Also, this result raises serious concerns over the heavy metal pollution status of the metropolis at large, as well as the rationale behind situating commercial swimming pools in the heart of population dense cities without adequate protections put in place.

\section{Conflict of interest}

No conflict of interest declared.

\section{References}

1. Vanloon GW, Duffy SJ. The hydrosphere. In: Environmental Chemistry: A Global Perspective 2nd Ed. New York: Oxford University Press; 2005:197-211.

2. Okoro HK, Adeyinka A, Jondiko OE, Ximba BJ, Kakalanga SJ. Assesment of heavy metals contamination in groundwater: A case study of central industrial district in Ilorin Kwara State, Nigeria. Int J Phys Sci 2012;7(28):5078-5088.

3. Ogunka-Nnoka C, Assor K, Onuoha S, Amadi P. A study of the toxicants and biomarkers of oxidative stress in soils plants and sea foods from Ebubu and Elele-Alimini communities in Rivers State. Ovidius U Ann Chem. 2018;29(1):1-7.

4. Nouri J, Mahvi AH, Babaei AA, Jahed GR, Ahmadpour E. Investigation of heavy metals in groundwater. PakJ Biol Sci 2006;9(3):377- 384.

5. Amadi AN. Quality assessment of Aba river using heavy metal pollution index. Am Environ Eng 2012;2(1):45-49.

6. Amadi AN, Olasehinde PI, Okosun EA, Yisa J. Assessment of the water quality index of Otamiri and Ora-miriukwa Rivers. Phy Int 2010;1(2): 116-123.

7. Glauner T, Kunz F, Zwiener C, Frimmel FH. Elimination of swimming pool water disinfection by-products with advanced oxidation processes (AOPs). Acta Hydrochim Hydrobiol 2005;33(6):585-594.

8. Barss P, Djerrari H, Leduc BE, Lepage Y, Dionne CE. Risk factors and prevention for spinal cord injury from diving in swimming pools and natural sites in Quebec Canada: a 44-year study. Accid Anal Prev 2008;40(2):787-797

9. Thickett KM, McCoach JS, Gerber JM, Sadhra S, Burge PS. Occupational asthma caused by chloramines in indoor swimming-pool air. European Resp J 2002;19(5):827-832

10. Bernard A, Carbonnelle S, Michel O, Higuet S, De Burbure C, Buchet J, et al. Lung hyperpermeability and asthma prevalence in schoolchildren: Unexpected associations with the attendance at indoor chlorinated swimming pools. Occup Environ Med 2003;60(6):385-394

11. Chiswell B, Wildsoet CF. The causes of eye irritation in swimming pools. Water Sci Technol 1989;21(2):241-244

12. Erdinger L, Kirsch F, Sonntag HG. Irritierende Wirkung von Nebenprodukten der Schwimmbadwasserdesinfection. Zentralbl Hyg Umweltmed 1998;200(5-6):491-503 (German)

13. World Health Organization (WHO) Water, Sanitation, and Health Team. Guidelines for safe recreational water environments - volume 2 swimming pools and similar environments. Geneva: World Health Organization 2006.

14. Agomuo EN, Amadi PU. Accumulation and toxicological risk assessments of heavy metals of top soils from markets in Owerri Imo state Nigeria. Environ Nanotechno Monit Manage 2017;8(1):121-126.

15. United States Environmental Protection Agency (USEPA). Screening 
Level Ecological Risks Assessment Protocol for Hazardous Waste Combustion Facilities. Appendix E: Toxicity Reference Values. EPA 1999;530-D99-001C vol 3 http://wwwepagov/epaoswer/hazwaste/ combust/eco-risk/voume3/appx-epdf

16. Standard Organization of Nigeria (SON). Nigeria Industrial Standard. Nigeria Standard for Drinking Water Quality (NSDWQ). ICS 130602007; 20:15-19.

17. Kumar M, Puri A. A review of permissible limits of drinking water. Indian J Occup Environ Med 2012;16(1):40-44.

18. United States Environmental Protection Agency (USEPA). Human health risk assessment protocol. EPA-530-D-98-001A. Washington, DC: U.S. Environmental Protection Agency. 1998.

19. United States Environmental Protection Agency (USEPA). Exposure Factors Handbook. Washington, DC: U.S. Environmental Protection Agency. 1997.

20. Datta PR. Human exposure analysis of swimmers to chlorinated cyanuric acid via oral routes. United States Environmental Protection Agency internal report. 1979: 307.

21. Beech JA. Estimated worst case trihalomethane body burden of a child using a swimming pool. Med Hypotheses 1980;6(3):303-307

22. Zeng X, Liu Y, You S, Zeng G, Tan X, Hu X, et al. Spatial distribution health risk assessment and statistical source identification of the trace elements in surface water from the Xiangjiang River, China. Environ Sci Pollut Res 2015;22(12):9400-9412.

23. Harshmi MZ. Concentration and human health risk assessment of selected heavy metals in surface water of the Siling reservoir watershed in Zhejing Province China. Pol J Environ Stud 2014;23(3):801811

24. United States Environmental Protection Agency (USEPA). Risk Assessment Guidance for Superfund. Volume I: Human Health Evaluation Manual (Part E Supplemental Guidance for Dermal Risk Assessment). Washington, DC: US EPA. 2004.

25. United States Environmental Protection Agency (USEPA). Selenium and Compounds; CASRN 1991;7782-49-2. https://cfpubepagov/ ncea/iris/iris_documents/documents/subst/0472_summarypdf
26. Okereke-Okonkwo CJ, Amadi PU. Accumulation and risk assessment of heavy metals contents of school playgrounds in Port Harcourt metropolis Rivers State. J Chem Health Safety;24(5):11-22.

27. Mann AG, Tam CC, Higgins CD, Rodrigues LC. The association between drinking water turbidity and gastrointestinal illness: a systematic review. BMC Public Health 2007;7(256):1-7.

28. Ratnaike RN. Acute and chronic arsenic toxicity. Postgrad Med J 2003; 79(933):391-396.

29. Naujokas MF, Anderson B, Ahsan H, Aposhian HV, Graziano JH, Thompson C, et al. The broad scope of health effects from chronic arsenic exposure: update on a worldwide public health problem. Environ Health Persp 2013;121(3):295-302.

30. Pacyna JM, Pacyna EG. An assessment of global and regional emissions of trace metals to the atmosphere from anthropogenic sources worldwide. Environ Rev 2001;9(4):269-298.

31. Omeire GC, Okafor DC, Eluchie C, Odimegwu NE, Nze SN, Anagwu FI, et al. Assessment of the quality of borehole water sample in Federal Housing Estate and Sites and Services areas of Owerri, Imo State, Nigeria. Food Sci Qual Manag 2015;42:5-12.

32. Lenntech. Heavy Metals 2011, cited 2019 \#\#\# \#\#.. Available from: http://www.lenntech.com/processes/heavy/heavy-metals/heavymetals.htm

33. Gohera ME, Hassan AM, Abdel-Moniem IA, Fahmy AH, El-sayeda SM. Evaluation of surface water quality and heavy metal indices of Ismailia Canal, Nile River, Egypt. Egypt J Aquat Res 2014;40(3):225-233

34. Horowitz Y, Greenberg D, Ling G, Lifshitz M. Acrodynia: a case report of two siblings Arch Dis Child 2002;86(6):453.

35. el-Fawal HA, Gong Z, Little AR, Evans HL. Exposure to methyl mercury results in serum autoantibodies to neurotypic and gliotypic proteins Neurotoxicology 1996;17(1):267-276

36. Hendry WF, A'Hern RP, Cole PJ. Was Young's syndrome caused by exposure to mercury in childhood? BMJ 1993;307(6919):1579-1582.

37. Kabata-Pendias A. Trace elements in soils and plants. 4th ed Boca Raton: CRC press Taylor and Francis Group; 2011. 